International Journal of Linguistics, Literature and Culture
Available online at https://sloap.org/journals/index.php/ijllc/
Vol. 7, No. 4, July 2021, pages: $241-254$
ISSN: 2455-8028
https://doi.org/10.21744/ijllc.v7n4.1720

\title{
Toni Morrison's Transgressive Literary Preaching and Folk Songs as Postmemory
}

Ousseynou Sy ${ }^{\text {a }}$

Article history:

Submitted: 27 March 2021

Revised: 18 April 2021

Accepted: 9 May 2021

\section{Keywords:}

archive;

aural;

mainstream Chirstianity;

oral;

postmemory;

rememory;

sermon;

\begin{abstract}
This paper intends to study the sermons or "literary preaching" and folk songs in Toni Morrison's fiction in the light of Marianne Hirsch's concept of postmemory. Drawing on Hirsch's postmemory then, this paper articulates that the "literary preaching" and folk songs function within Morrison's novelistic discourse as postmemory medium that presses against the erasure and the death of a culture and history. The folk songs and "literary preaching" are mediums of transgenerational transmission of trauma and history. Hirsch defines postmemory as the memories that the survivors of trauma bequeathed to their children and grandchildren. Hirsch presents photographs as the instrument through which postmemory is archived and conveyed. She talks about "photographic archive" since photographs can bring back their referents. In comparison, the sermons and folk songs are analyzed as "oral/aural archive", for they have the attribute of triggering memory and postmemory. Also, through her literary preaching, Morrison deconstructs and questions mainstream Christianity by blending it with unorthodox Christian practices. For example, Baby Suggs' sermon in Beloved gives precedence to the flesh over the spirit, and this sermon is remembered throughout the text as a subdued metaphor. Pilate's sermon in Song of Solomon flips around the sexism and patriarchy in orthodox Christianity and at the same time fills in the holes in the "Archive Fever". Pilate's sermon builds on Jarena Lee's.
\end{abstract}

International journal of linguistics, literature and culture (ㅇ 2021. This is an open access article under the CC BY-NC-ND license (https://creativecommons.org/licenses/by-nc-nd/4.0/).

Corresponding author:

Ousseynou Sy,

Distinguished Alum of the University of Texas at Austin, United States

Email address: ousseynou2002@gmail.com

\footnotetext{
${ }^{a}$ University of Texas at Austin, United States
} 


\section{Introduction}

In the opening epigraph, Morrison calls for a critic who can deconstruct the core cultural forms that are at the cornerstone of her fiction. She gives some hints to the acute critic that she longs for. The acute critic has to find out the meaning and significance of her fiction within the religion ("church" and "chorus") and the tradition ("community" and "ancestor"). The authorial sensibility of Morrison's writing is therefore twofold: it is centered around religion, the black church tradition, and the African American folk tradition. The church and folklore are the major cosmological components of Morrison's novelistic universe.

This paper analyzes how these two essential components of Morrison's writing function mainly in Baby Suggs' sermon in Beloved in the Clearing and Pilate's "extemporaneous sermon" in Song of Solomon. These two sermons are subversive since they depart from mainstream Christianity. Also, the sermonic discourse and folk songs capture the temporality of memories. The folk songs function as a palimpsest upon which the novelistic discourse superimposes itself (Cole, 2021; Connor, 2010; Crownshaw, 2004). This oral form that is overridden by the written text is both a linguistic and epistemic resistance of mainstream American ideology. It is an alternative against the legal prohibition against literacy for the slave. Drawing on Marianne Hirsch's postmemory, this paper shows that the sermonic discourse and folk songs are postmemory mediums through which memory and rememory are bequeathed to the next generation. The paper starts by giving a historical overview of the church and folk songs in African American culture and discusses their centrality.

\section{The Centrality of the Church and folk songs in African American culture:}

The first authorial sensibility in Morrison's work derives from the church. For a community that has been scattered and dismembered, the church becomes a means of binding together a lost and homeless people. The church becomes the home and the community. At home, you are accepted unconditionally, you have self-worth and self-respect. The African American church confers this self-esteem and self-worth on blacks that mainstream American society denies them (DuBois, 1903). In the church, they can escape the white normative gaze and can express themselves freely. That is why it is no coincidence that the black church has generated the first freedom fighters in the African American community like Fannie Lou Hamer and Martin Luther King and so forth ${ }^{\mathrm{b}}$. The churches are removed from the state and yet they are centers of power (Lincoln \& Mamiya, 1990). The church obliterates, for example, the I-IT relations that blacks often experience in a white structured world. Within the church, they experience an I-Thou relation. In other words, around the church, the African American community builds her identity and sense of belonging. Mary Pattillo-McCoy in "Church Culture as a Strategy of Action in the Black Community" sums up the centrality and the role of the black church in these terms :

The black church is the anchoring institution in the African American institution (DuBois, 1903; Lincoln \& Mamiya, 1990; Myrdal, 1944). The church acts simultaneously as a school, a bank, a benevolent society, a political organization, a party hall, and a spiritual base. As one of the few institutions owned and operated by African Americans, the church is often the center of activity in black communities. (p. 769)

As Pattillo-McCoy highlights here, the church plays many a role in the African American community. And further, in her essay, Mary Pattillo-McCoy articulates how the church operates as an institution around which the disparate fragments of the African culture that slavery has scattered are gathered. Through her argument, we can infer that the church stands for a metaphysical expression of yearning for what has been lost. It is the place where the enslaved, incarcerated, and now policed body of the African-American can be elevated. Mary Pattillo-McCoy describes this uplifting or metaphysical transcendence that the church confers on the African American congregants in this passage:

In the black Christian view, freedom is an explicitly collective endeavor signifying both spiritual deliverance into God's kingdom and worldly deliverance from the material realities of racial oppression. Using the call-andresponse style, the preacher and the congregation, in musical and verbal cooperation, make the journey toward freedom as one body (Hamilton, 1972; Levine, 1977). (p. 770)

${ }^{\mathrm{b}}$ For a comprehensive analysis of the Black Church as it relates to the history of African Americans and to contemporary black culture, see C. Eric Lincoln and Lawrence H. Mamiya's The Black Church in the African American Experience, published in Durham: Duke University Press, USA, 1990. 
The church becomes then the place where the African American can attain both physical and spiritual freedom.

The second authorial sensibility in Morrison's writing resides in the Negro folk songs. In her 1981 interview with Thomas Leclair entitled "The Language Must Not Sweat", Leclair asks Morrison the following question about the distinctiveness of her fiction, and Morrison replies that the distinctiveness of her fiction resides solely in her use of language. Here runs that part of the conversation between Leclair and Morrison :

LeClair: As an editor, you look for quality in others' work. What do you think is distinctive about your fiction? What makes it good?

Morrison: The language, only the language. The language must be careful and must appear effortless. It must not sweat. It must suggest and be provocative at the same time. It is the thing that black people love so much - the saying of words, holding them on the tongue, experimenting with them, playing with them. It's a love, a passion. Its function is like a preacher's: to make you stand up out of your seat, make you lose yourself, and hear yourself. The worst of all possible things that could happen would be to lose that language. (pp. 123-124)

Morrison compares here her novelistic discourse to the language of the preacher. The language of the preacher often builds on folk songs, folk tales, and proverbs. W.E.B. Du Bois's work The Souls of Black Folk discusses the centrality of folk songs in the black culture. In the last chapter of his book entitled "The Sorrow Songs," W.E.B. Du Bois introduces and analyzes the different spiritual songs which he calls Negro folk songs. He articulates that these songs are "the rhythmic cry of the slave" (p.156) that expresses the trauma, death, hope and faith of the enslaved African in America. He proposes this definition of the Negro folk song:

\begin{abstract}
...these songs are the articulate message of the slave to the world... They are the music of an unhappy people, of the children of disappointment; they tell of death and suffering and unvoiced longing toward a truer world, of misty wanderings and hidden ways... and in it, we can trace here and there signs of development. (p.157)

Du Bois explains that the Negro folk song is bequeathed from one generation to another, and it still has the same significance and impact on each generation. Du Bois writes: "The child sang it to his children and them to their children's children, and so two hundred years it has traveled down to us and we sing it to our children, knowing as little as our fathers what its words may mean, but knowing well the meaning of its music." (p.158)
\end{abstract}

As Du Bois suggests in the preceding passage, the context under which the folk song is written may be unknown to each generation that inherits it, but the meaning and significance of the song is something that each generation can easily grasp (Derrida, \& Ronell, 1980; Derrida, 1996; Du Bois, 1994). Morrison in Beloved describes these songs as “...flat-headed nails for pounding and pounding and pounding." (p. 48) This means that any person in Sweet Home can seize and appropriate these songs. They are often 'authorless' because the chain of transmission is so long that it becomes difficult to figure out the first person who originated them. Their main intent is to archive a culture, a history, and a tradition. By defining the folk songs as "...flat-headed nails for pounding and pounding and pounding" (p. 48), Morrison sets them as a memorabilia reservoir for the preservation of slave residuals. The underlying message that is then easily graspable and transmittable is the rhythmic cry of trauma, struggle, perseverance, and hope of the enslaved ancestor. This transparent message embedded in the folk song allows me to read it as a postmemory medium since it enables a linear transmission of memory and history despite the opacity surrounding its birth context.

Marianne Hirsch who theorizes postmemory uses photographs to analyze how the memories of the victims of trauma can be passed on to the next generations to the point that it becomes memories of their own. Hirsch argues that postmemory describes :

The relationship of children of survivors of cultural or collective trauma to the experiences that they 'remember' only as of the narratives and images with which they grow up, but that are so powerful, so monumental, as to constitute memories of their right. (p.9)

Much like images (photographs), folk songs and sermons are narratives that salvage and preserve memories. For example, Sethe describes her unforgettable slave experience as "a thought picture" (p.43), which is a periphrastic equivalent of rememory. The point that is being made here is that Morrison makes folk songs and sermons function as postmemory medium much like images. In other words, if Hirsch talks about "photographic archive" in using photographs to analyze how postmemory works in post-holocaust children, the folk songs are, in comparison, "oral/aural archive"' through which memory and history are handed down to the descendants of slavery. The folk

Sy, O. (2021). Toni Morrison's transgressive literary preaching and folk songs as postmemory. International Journal of Linguistics, Literature and Culture, 7(4), 241-254. https://doi.org/10.21744/ijllc.v7n4.1720 
song then is not only a bequest but also a substitute memory or compensatory memory that is meant to offset a historical amnesia or erasure. In other words, as "oral/aural archive," the folk song enables some sort of historical continuum. This comparison between Hirsch's "photographic archive", and what I call "oral/aural archive" is not farfetched at all since Hirsch extends the concept of postmemory to a much wider cultural inheritance that transcends racial and national boundaries. In this respect, she broadens the definition of postmemory in these terms :

Defined through an identification with the victim or witness of trauma, modulated by an unbridgeable distance that separates the participant from the one born after. [...] Postmemory would thus be retrospective witnessing by adoption. It is a question of adopting the traumatic experiences - and thus also the memories - of others as experiences one might oneself have had, and of inscribing them into one's own life story" (p.10; emphasis by Hirsch's).

Hirsch's definition of postmemory as retrospective witnessing by adoption coheres with Helena Woodard's definition of rememory in Slave Sites On Display. Woodard writes: “ " .. 'rememory' the complex evocative concept that she (Morrison) coined in Beloved, which explains the importance of knowing the slave past but without the perils of its repetitive practices.' (p. 12) Rememory is then an ongoing reflection on memory; it is a living present. In the same vein, postmemory can be viewed as a reflection on an inherited memory. With rememory there is tight retention of the past while postmemory memory appears as a strong living link binding the victims of trauma with their descendants. Both rememory and postmemory deny the past an ontological status, for the past are embedded in the present and vice versa. In the light of Hirsch's definition of postmemory, the sermonic discourse and folk song allow a "retrospective witnessing by adoption" since they become a living link between those who lived the experience and those who just appropriate it. Baby Suggs' sermon "Love your heart" in which the "flesh becomes vested with religious significance typically reserved only for the soul" (p.36), as Matthew Smalley points out, is appropriated by many members of the community through a "retrospective witnessing by adoption." As we recall Baby Suggs renounces her "Love your heart" sermon later in the novel and yet it is still passed on and vividly remembered in different sections of the narrative.

\section{Baby Suggs' recalled sermon remembered:}

Textually, Baby Suggs' sermon is grounded as memory and rememory on the text. Indeed, when the novel opens in 1873, Baby Suggs had already died. The narrative structure catalogs then Baby Suggs as an ancestor. And her sermon becomes personified, bringing forth another character who is remembered and talked about as a subdued metaphor. That's why Matthew Smalley's term of "circulated sermon" is very relevant in analyzing the omnipresence of Baby Suggs' sermon. As a matriarch and community sermonizer, Baby Suggs' recalled sermon or "circulated sermon" becomes the oral/aural body that brings together the community. Roxanne R. Reed examines Baby Suggs' recalled sermon in "The Restorative Power of Sound" as a sound, a piece of music, that works as communicate catharsis. Baby Suggs' recalled sermon inscribes itself into the narrative economy as memory and postmemory. Here goes Baby Suggs' sermon when it is first delivered:

After situating herself on a huge flat-sided rock, Baby Suggs bowed her head and prayed silently. The company watched her from the trees. They knew she was ready when she put her stick down. Then she shouted, "Let the children come !' and they ran from the trees towards her... Here . . . in this place, we flesh; flesh that weeps, laughs; flesh that dances on bare feet in the grass. Love it. Love it hard. Yonder they do not love your flesh. They despise it. They don't love your eyes; they'd just as soon pick em out. No more do they love the skin on your back. Yonder they flay it. And $\mathrm{O}$ my people they do not love your hands. Those they use, tie, bind, chop off and leave empty. Love your hands! Love them. Raise them and kiss them. Touch others with them, pat them together, stroke them on your face 'cause they don't love that either. You got to love it, you!. . You got to love it. This is flesh I'm talking about here. Flesh that needs to be loved... And all your inside parts that they'd just as soon slop for hogs, you got to love them. The dark, dark liver - love it, love it, and the beat and beating heart, love that too. More than eyes or feet. More than lungs that have yet to draw free air. More than your life-holding womb and your life-giving private parts, hear me now, love your heart. For this is the prize. Saying no more, she stood up then and danced with her twisted hip the rest of what her heart had to say while the others opened their mouths and gave her the music. (pp. 103-104)

Baby Suggs gives here a sermonic discourse that extols the body in a very descriptive and sensual manner. But later she distances herself from the sermon. And yet, like memory or rememory, it is already deeply engraved in the collective consciousness. In this respect, Smalley writes: "Put in the terms of the novel, Baby Suggs' rejected sermon is "remembered", throughout the text, and her "call" generates multiple communal responses." (p. 31) 
Baby Suggs' recalled sermon, which Smalley calls rightly "circulated sermon," has as much effect on the congregants and other characters as when first delivered. To a great degree, a story conveyed through a sermon that subverts religious principles is harder to erase from collective consciousness than a simple secular story let loose. Baby Suggs' sermon becomes like Sethe's "thought picture" that does not want to go away. Sethe remembers Baby Suggs' sermon in this passage:

In the Clearing, Sethe found Baby's old preaching rock and remembered the smell of leaves shimmering in the sun, thunderous feet, and the shouts that ripped pods off the limbs of the chestnuts. With Baby Suggs' heart in charge, the people let go. (p.111)

Baby Suggs' sermon works like a positive rememory that the community claim despite Baby Suggs' death and her renunciation of the sermon. Therefore, unlike Beloved whom, the community wants to forget "like a bad dream" (p. 323), Baby Suggs' sermon works against time. It works towards the materialization of memory. Sethe's remembrance of Baby Suggs' sermon is first triggered off by the "old preaching rock" and The Clearing. Both of these things have become historical signifiers that catalog Baby Suggs' recalled sermons. The "old preaching rock" works here as an object of memory or artifact, and an artifact has "the potential to recall a past event or incident immediately through a mnemonic association with that event"' (p. 126) as Helena Woodard writes. Woodard further articulates that "artifacts can help illustrate willed forgetfulness or self-protective nostalgia." (p.126) Sethe's remembrance scene expresses her self-protective nostalgia; and the scene beautifully turns a spatial, aural, and visual narrative into a powerful fabric of remembrance. To echo Hirsch, these historical signifiers become the referents of the sermon's photograph. In other words, drawing on Steven Connor's groundbreaking essay "Thinking Things", we can articulate that the "old preaching rock," the Clearing, and the "smell of leaves" become thinking things since they are things that are "apt to embody thought." (p. 1) These 'thinking things' in Sethe's remembrance scene embody both thought and memories. Because of the 'thinking things' that inhabit it, the Clearing has become then a commemorative site. Indeed, the fact that Sethe can have her memories awakened just by being in the Clearing reminds us of Andreas Huyssen's assumption that:

The temporal status of any memory is always the present and not, as some naïve epistemology might have it, the past itself, even though all memory in some ineradicable sense is dependent on some past event or experience (p.3)

Sethe's experience of Baby Suggs's sermon is like her 'thought picture', they may be dormant but they are ineradicable. Sethe's recollection of Baby Suggs' sermon illustrates that a dormant memory can be quickly awakened when in contact with a place of memory or object of memory. That is why memory is an active instrument in the creation and perpetuation of a counter-amnesia culture.

Lisa Woolfork's concept of 'bodily epistemology' can clarify, too, Sethe's mnemonic experience in the Clearing. Lisa Woolfork argues that 'bodily epistemology' enables the visitor or spectator of a place that houses memory, such as a slave site or museum to figuratively put on the skin of the slave's body double or likeness. Helena Woodard elaborates further that through 'bodily epistemology', "“ the spectator approximates the presence of the enslaved subject when cast in a "subcutaneous transmission of the past to the present.", (p.127) It is some "bodily epistemology' that allows Sethe to commune wholeheartedly with Baby Suggs' memory. Such communion with Baby Suggs' memory shows that memory does act as an archive despite its fluidity and volatility.

The narration presents other passages in which it is an absence that engenders memorabilia. For example, the eight absented children of Baby Suggs are like Sethe's 'thought picture'. Nothing can fill up the absence of Baby Suggs' runaway and scattered children. As Connor points out quoting Derrida, "'quelque-chose manque à sa place, mais le manque n'y manque jamais' - 'some-thing is missing from its place, but the lack is never missing from it.", (p.2) the eight absented children of Baby Suggs who can never be disremembered by their mother are related in this passage:

Great God, she thought, where do I start? Get someone to write old Whitlow. See who took Patty and Rosa Lee. Someone name Dunn got Ardelia and went West, she heard. No point in trying for Tyree or John. They cut thirty years ago and, if she searched too hard and they were hiding, finding them would do them more harm than good. Nancy and Famous died in a ship off the Virginia Coast before it set sail for Savannah. That much she knew. The overseer at Whitlow's place brought her the news, more from a wish to have his way with her than from the kindness of his heart. (p.169)

Sy, O. (2021). Toni Morrison's transgressive literary preaching and folk songs as postmemory. International Journal 
As it stands out in the quotation, Baby Suggs' desire to remember and her unbearable pain of remembering her dismembered family clash with each other. Absence triggers here a memory that is quiescent and yet active. Another character who remembers Baby Suggs' sermon is Denver. Denver who was a child when Baby Suggs' sermon was delivered remembers or has some hallucination about it in this section:

\begin{abstract}
"She said for me not to listen to all that (the slaves not having the right to have pleasure with their body). That I should listen to my body and love it"' (p. 247). And Denver goes on to relate how on her Grandma's burial her sermon is still stuck with people including herself.
\end{abstract}

She states:

I know Grandma Baby would have liked the party and the people who came to it because she got low not seeing anybody or going anywhere - just grieving and thinking about colors and how she made a mistake. That what she thought about what the heart and the body could do was wrong. (Emphasis added, p. 247)

These different passages remembering Baby Suggs' sermon pieced together illustrate that her sermon has become wittingly or unwittingly a memory for some, a rememory for others, and a postmemory for the younger generation of the community. That's why Denver, to whom her Grandma's sermon is a rememory, does not try to rationalize or critique her Grandma's decision of renouncing her sermon. She just embraces it as a strong advice "That I should listen to my body and love it" (p. 247) In this regard, Smalley writes: "In part, Denver's remembrance of her Grandmother draws on the knowledge of Baby Suggs' message of self-love and the holiness of the black body" ( $p$. 40)

Baby Suggs' sermon despite its unfamiliar venue conveys a profound religious message that goes counter to mainstream Christianity. Baby Suggs' sermon is delivered in the Clearing, not in a church; and yet it touches on themes of deliverance, freedom, self-worth, self-love, and self-respect. Mary Pattillo-McCoy sees these themes as central to the black church. In this respect, she writes: Black Christian spirituality is based on themes of deliverance and freedom (Cone, 1977; Levine, 1977; Marable, 1989; Smith, 1995; West, 1982).

The freedom aspired to and attainable through religion differs from the Euro-American notion of freedom as the Individual's free choice, or the individual's freedom from the actions or beliefs (Bellah et al., 1996) (p.770) Baby Suggs' sermon has this Black Christian spirituality dimension since it delivers the congregants from the oppression of the yonder. In addressing her audience, Baby Suggs sets the Clearing against the yonder. Also, the circularity of Baby Suggs' sermon fits into Morrison's rejection of linearity. Indeed, a community where “... men and women have moved around like checkers" (p. 27) loses a sense of linear time. To endorse linearity is to reckon constant linear progress, which is not the case with Morrison's incarcerated and now policed community. ${ }^{c}$

Moreover, Baby Suggs' sermon operates as music. It draws on what Reed calls "the triplet figure" (p. 61) because of its rhythmic pattern. Baby Suggs' sermon then instead of becoming a mere random utterance becomes a well-organized sound that fits into the "unarticulated, unformed, and undefined" oral and aural experience that informs Beloved as Reed articulates. (p. 57) To elaborate on Reed's argument, we can add that Baby Suggs' sermon is, too, a communical and cathartic sound that goes hand in hand with the sound exorcising scene of Beloved that closes the novel.

As we recall by the end of the narration when the women gathered to exorcise Beloved through chants and Christian and pagan prayers, the narrator sets the word against the sound (Najman et al., 1988; Kim, 2002; Gepu et al., 2018). The narrator says, "In the beginning was the sound and they all knew what that sound sounded like." (p. 305) In this sound cleansing scene, the song is meant to chase Beloved and ease Sethe's burden of guilt as well as the community's. Ella's infanticide is, for example, revealed to the reader. She has the strongest empathy toward Sethe since "she had delivered, but would not nurse, a hairy white thing, fathered by the "lowest yet." It lived for five days never making a sound. The idea of that pup coming back to whip her too set her jaw working, and then Ella hollered." (p. 305) in the narration, the sound is not only susceptible to triggering a memory or postmemory, but also it is a life-giving and remedial force.

Ella's utter identification with Sethe's crime could be justified through Lisa Woolfork's "body epistemology". Sethe's act is pregnant of memory since it reactivates the memory of any mother who committed, against her will,

c For a thorough analysis of Morrison's rejection of linearity, see my paper: “Toni Morrison and Ralph Ellison's Oraliture: Writing Fiction against the Grain." Metacritic Journal for Comparative Studies and Theory 5.1 (2019). 
the same crime. In other words, Sethe's infanticide is turned into a mnemonic act through which Ella tries to reconcile herself with her very crime. That's why the narrator relates that "Whatever Sethe had done, Ella didn't like the idea of past errors taking possession of the present." (p. 302) Overall in Morrison's text, the sound is given primacy over the word. That's why not only does Baby Suggs' sermon permeate the narration but also it is juxtaposed with other textures of folk songs.

As Reed illustrates Beloved evinces " "... the passing down of survival wisdom through stories in the form of the song' (p. 59). In the light of Reed's argument, it would be accurate to read these folk songs as sankofa elements. Sankofa, in Ghanaian cosmology, refers to the need to go back to the past to shape the future. Sankofa enables the past to inform the present. In this respect, Helena Woodard writes: “ ... in constantly looking back, it (Sankofa) warns of mistakes from the past that might prove destructive for the future." (p. 57). The folk song that Reed identifies as having the attribute of passing on survival wisdom is steeped in Sankofa since it teaches how to learn from the trauma of the past. Even rememory is a sankofa instance since the victim of trauma delves into his painful past to excavate buried memories for healing and guidance purposes. In this regard, the folk song, as a historical and cultural legacy, carries such an evocative historical resonance that when enacted in the novel discourse, it becomes a healing commemorative music. Some songs sing the perseverance of the slaves. Others that sing the boredom in Sweet Home. For example, in these two passages, Paul D sings respectively the boredom, the stale life, and the endless work prevailing in Sweet Home:

Little rice, little bean,

No meat in between,

Hard work ain't easy,

Dry bread ain't greasy. (p. 48)

Lay my head on the railroad line,

The train comes along, pacify my brain.

If I had my weight in time,

I'd whip my captain till he went stone blind.

Five-cent nickel,

Tent-cent dime,

Busting rocks is busting time. (p. 48)

These songs are part of the "rhythmic cry of the slave" and are meant to ease the burdens of enslavement. Much the same is true with the songs sung in Sweet Home "... where yearning fashioned every note" (p. 48) as the narrator points out in Beloved. As an example, let's focus on the first song where Paul D expresses his yearning for nutritious food. This yearning of Paul D is enacted by Sixo when he killed the shoat to feed himself in part II of the book (I will pick up this point later). As an oral/aural object of memory, the folk song becomes an ink in the narrative economy through which Morrison writes down the trauma, struggle, hope, and triumph of her community. As slave residuals, folk songs have constant themes some of which Woodard identifies as "... sublimated coded messages for escape, easing the burdens of enslavement, and embracing a power deemed superior to that of the slave master.' (p. 93). The modern African American whose body is now policed can easily identify with any of these folk songs. He or she can seize and appropriate these songs and make them fit into his or her present-day reality. Yet, it has to be reckoned that the folk song can't account for the very historical circumstances under which it was created. Since its genesis is not transmittable, there is significant historical information omitted. Hirsch's "photographic archive" compels the same logic as the "oral or aural archive." As Soji Cole writes, "the photograph does not tell the whole story of the subject" (p. 2) since there are always other things uncaptured in the picture it crystallizes, immortalizes, and bequeaths to the next generation. However, despite these limitations, "the photographic archive" like the "oral or aural archive" remain powerful instruments through which some levels of historicity, authenticity, and reality about the past are recorded (Wulderet al., 2016; Rose, 2000). Another functionality of the "rhythmic cry of the slave"' songs is purely aesthetic. These songs are a means of doing language. In her Nobel lecture, Morrison eloquently articulates that language has an ontological dimension, it is a living thing, and that man can do and undo language. She writes: "We die. That may be the meaning of life. But we do language. That may be the measure of our lives." (Morrison, Nobel Lecture) Since language carries an ontological dimension, maternal songs are used to evoke memory like the maternal songs that Sethe sings to Denver. Reed, drawing on Holloway's work "Lyrical Dimensions of Spirituality," explains that these maternal songs "dictate cultural identity and bring order to the African American

Sy, O. (2021). Toni Morrison's transgressive literary preaching and folk songs as postmemory. International Journal 
community" (p. 70). I would go beyond Reed to argue that these maternal songs are cognitive sounds, and they are grounded on epistemes and linguistic patterns that are alien to the western canonized knowledge and logic. Thereby they expose the intelligence, genius, and resistance of the slave. For example, Woodard mentions the North Star song/spiritual that "helped runaway slaves find and follow the North Star to freedom." (p. 93) Hence, embedded within the folk song is an oral episteme, and it is through this oral episteme that postmemory can be generated and passed on. I mean the folk song functions within the novelistic discourse both as an epistemic and linguistic resistance of Hellenistic ideology and Hamitic hypothesis, and as an alternative means of communication for the illiterate enslaved community. The folk song is set against the legal prohibition against literacy for the slave. Paul D's songs of yearning and perseverance along with the maternal songs that permeate the text release altogether an aural effect that metaphorically bridges not only written text and oral discourse but also two epistemic realms that move poles asunder (Gu et al., 2004; van der Waal, 2010). Baby Suggs herself is an embodiment of this oral culture that hides a whole civilization underneath.

\section{Baby Suggs' subversive sermon:}

Morrison's use of sermons is subversive. Her use of sermons which Matthew Smalley calls "literary preaching" is complex because within her literary preaching she questions the overarching patriarchy within Christianity and the spirit normative interpretation of the scriptures. For example, Baby Suggs' sermon "Love Your Heart" puts the flesh over the spirit, which goes against the grain of mainstream Christianity. Baby Suggs' sermon becomes therefore outstanding because of its content and poetics.

Not only does Baby Suggs flip around the discourse of mainstream Christianity to give agency to the flesh but also her sermon is a feminist discourse that tries to restore justice for women. Indeed, in mainstream Christianity most preachers are men, and women are often hemmed into the role of the church choir. Baby Suggs' sermon is a revisionist narrative that calls into question the received Christian dogmas. That's why Matthew Smalley calls Baby Suggs an "unchurched preacher." Baby Suggs' iconoclastic sermon takes place in the Clearing. A place that nature has granted them in contrast to a church, a place chosen and built by man. In her essay, "From Eden to Paradise: A Pilgrimage through Toni Morrison's Trilogy," Shirley A. Stave explains Morrison's intention to reject certain dogmas governing mainstream Christianity. Among these dogmas, she mentions Morrison's rejection of Christianity's "metaphorizing God as the father" (110), it's privileging of the "spirit over flesh" (117), and "the pettiness of God . . . as he is portrayed in the Old Testament" (113). The decision of Morrison to have recourse to literary preaching and at the same time question, the principles structuring Christianity is paradoxical. By using literary preaching, she values an entrenched culture and tradition rooted in orthodoxy. One way of analyzing this paradox is that Morrison wants to use the same tool within Christianity to flip around its orthodoxy. In so doing, Morrison's literary preaching chokes and alienates mainstream Christianity. And this tentatively mimics the alienation of the black women within the church. Therefore, Baby Suggs' sermon is meant to break a patriarchal religious power structure (Hirsch, 2001; Huyssen, 1995; Lincoln, \& Mamiya, 1990). Baby Suggs' sermon that extols the flesh is abuse and alteration of mainstream Christianity. Baby Suggs appropriates mainstream Christianity and fuses it with her intent. Baby Suggs' sermon is in a Bakhtinian sense a heteroglot opinion that is in tension with mainstream Christianity. The discourse of mainstream Christianity has often been used to allow and perpetuate male domination. The ambivalence, skepticism, and repulsion that Morrison has towards mainstream Christianity are dextrously summed up by Smalley in this passage:

Despite Morrison's attraction to the energy, openness, and sensuality of the sermon, she has an intensely ambivalent relation to invoking the sermon for several interlocking reasons. First, Morrison holds the form at arm's length because it tends to reify highly centralized structures of authority and, more broadly, to fortify culturally dominant modes of Christianity that fail to address the needs of African Americans, especially women and children. Second, although Morrison compares her literary style to that of a preacher, her intricate strategies of characterization reveal an attempt to navigate a dialectic of desire and repulsion as she constructs her vocational identity about her numerous fictional preachers. Her attraction to the preacher's verbal artistry, moral authority, and cultural insight exists in dialectical tension with her repulsion at the preacher's hubris, elitism, and tendency to privilege abstractions over the needs of the body (Morrison \& LeClair, 1981; Pattillo-McCoy, 1998). Consequently, Morrison's intentionally multivalent scenes of preaching throw the reader into interpretive crisis and demand patient critical attention. (p. 30)

As Smalley highlights the church has its inner flaws that Morrison distances herself from. Her repulsion of the preacher's hubris and elitism calls on the attention of the reader. Hubris and elitism kill the inclusiveness and hearth that the church is supposed to embody because the preacher speaks on behalf of and to a people who have been 
denied literacy through the legalized system of oppression during slavery and in the Reconstruction. For example, the Black Codes was enacted in the Reconstruction. Morrison wants to incorporate into mainstream Christianity unorthodox feminine characteristics to question the mainstream narrative of success and equality that shapes the black church. The untaken care concerns of children and women that Morrison deplores is an example in this regard. Reading Baby Suggs' sermon in the light of Morrison's stance toward the church reveals a sermon that revises the received mainstream Christianity by inscribing the history of the marginal congregants, the children, and the women. She carries the same agenda in Song of Solomon.

\section{Pilate's subversive sermon:}

Another sermon in Morrison's text that goes counter to mainstream Christianity and engages with the archives is Pilate's sermon in Song of Solomon. Pilate interrupts the sermon of the preacher in the eulogy of Hagar's death. A lady interrupting a preacher is an unorthodox reaction and it turns the sermon into a contested site wherein two voices carrying different agendas are in clash (Peterson \& Peterson, 2001; Reed, 2007; Smalley, 2018). Also in mainstream black Christianity, the sermon always ends with happy notes no matter the notes or circumstances under which it begins. But Pilate's intervention in the sermon ends it with sadness. Pilate is the daughter of her father so to speak. As we recall her father rejects the biblical meaning of Pilate as the "Chirst killer." He finds the shape of the word Pilate in the Bible beautiful since it reminds him of a giant tree hovering over smaller trees. The fact that Pilate desecrates the priest's sermon by seizing herself on the floor refers to Morrison's refusal to conform to preconceived precepts. In other words, through Pilate's forced intervention into the sermon, Morrison seems to suggest that certain aspects of religion have to be conceived within a framework of dialogue and agreed-upon understanding, and the women have to be at the center of this dialogue.

Pilate imposing herself as a female ministry recalls Jarena Lee, the first African American woman to be granted a license to preach after a long battle with the establishment of the Methodist Church. Frederick Knight in "The Many Names for Jarena Lee" narrates the brave history of Jarena Lee. Frederick Knight relates that Jarena Lee received a divine call commanding her to preach the Gospel but the male authorities of the Methodist Church refuse to let her preach. But she perseveres and eight years later while a preacher fainted amid his sermon, Jarena Lee picks up the sermon much to the surprise of the congregants (Stave, 2014; Woodard, 2019; Lisa, 2009). Thereby, she started preaching despite the hostilities from her ministry. Pilate's interrupting of the preacher's sermon in Morrison's text is pretty much modeled after that of Jarena Lee. Both of them are black women convinced that Christ has died to save mankind but not just a particular gender. Therefore the Word has to be gender and race-blind. Another detail that makes Pilate and Jarena Lee's sermons squarely overlap is that Morrison characterizes Pilate's sermon “extemporaneous"' (p. xiii) in her 2004 foreword to Song of Solomon, which captures the circumstances from which Jarena Lee's sermon springs. Pilate's breaking of the preacher's sermon illustrates that Morrison prefers a call-andresponse preaching style wherein the voice of the preacher and that of the congregants become one. Morrison's writing is then deeply informed by sermons. Pilate's sermon is meant to remember Jarena Lee's. On the one hand, Jarena Lee's sermon inscribes itself in the narration as a memory to the informed reader, and on the other hand, it grafts itself onto the archives as a rememory since it is intended to cure the 'archive fever'. Morrison's complex use of literary preaching engages then with both the archives and a canonized tradition in American literature. In this respect, Smalley writes:

From the mid-nineteenth century through the present, US authors have engaged in this literary form (sermon) to voice eloquent and forceful dissent from their milieus and to promote alternative imaginations of community, the self, religion, or politics. (p.31)

Drawing on Smalley's quotation, we can argue that the preacher whose role and discourse Morrison subverts in both Baby Suggs and Pilate's sermons address both the religious and the political. The preacher, whose sermon has an impact in the social, political, and religious realm, can make and unmake principles. Therefore, the preacher is like the white slave master. The slave master defines and controls the identity of the slave. He imposes himself like a hegemon to the slave as the preacher imposes himself to his congregants. For example, the Schoolteacher in Beloved is the perfect white master-like preacher. He holds a discourse that dehumanizes the slaves. He defines the linguistic and epistemic realm of the slaves. He calls the language of slaves "Backtalk'. An example worth analyzing in this regard is the poignant passage about the shoat that Sixo killed and ate assuming that having healthy workers improves Sweet Home's overall yield. But even though Schoolteacher approves Sixo's rationale, he nonetheless

Sy, O. (2021). Toni Morrison's transgressive literary preaching and folk songs as postmemory. International Journal of Linguistics, Literature and Culture, 7(4), 241-254. https://doi.org/10.21744/ijllc.v7n4.1720 
flogs him to let him know that "definitions belong to the definers, not the defined." (p. 225) Six refuses to let Schoolteacher call his act theft because he wants to improve the overall property of the Schoolteacher. When we read this reasoning battle revolving around logic and linguistics between Sixo and Schoolteacher within the preacher and congregants paradigm, it becomes clear that Sixo rejects the monopoly of meaning. In other words, like Pilate's "extemporaneous sermon" which breaks down the hierarchy existent in mainstream Christianity where the preacher holds powerful sway over the congregants who are at the same time obliged to listen and denied the chance to talk back, Sixo's rejection of hegemony and monopoly of meaning cohere as a whole. Also, the other linguistic and legal issue that Sixo's refusal to let Schoolteacher call his act theft entails is that can a property who has no legal standing steal something that is also a piece of property. In other words, can a piece of property steal another piece of property? The schoolteacher does not either see the implications of Sixo's answer or he simply decides to shirk such a conundrum. This question is first and foremost implicitly raised by the grand subtext narrative on which the story of Beloved builds: Margaret Garner's killing of her children. On what legal ground is Sixo or Margaret Garner going to be tried? In the text, the Schoolteacher replies to Sixo's answer ("No, sir. It ain't (that's not stealing) ?') with "What ?" (p. 224) By responding with a question, the Schoolteacher closes a door that leads to serious legal and linguistic concerns. These unanswered questions or questions that build on other questions or questions that are simply answered by silence are recurrent in Beloved. These recurrent silences drive the reader to critically engage with what Woodard calls the "colossal failures in the archival record." (p. 4) Because of the "colossal failures in the archival record" names like Jarena Lee and Margaret Garner are rarely mentioned in history books. As Frederick Knight suggests Jarena Lee's name has "faded from the historical record" (p. 60) despite her tremendous contributions to the African American women's history and the history of American Christianity. Knight informs us that even Jarena Lee's name is spelled differently in the archive "Jarina" and "Gerenia". In this respect, Knight writes:

As demonstrated above, the Pennsylvania Abolition Society spelled her name "Jarina." The 1860 federal census misspelled her name and listed Lee as both male and a "washerwoman." Paradoxically, documents with such inaccuracies nonetheless yield information that may help answer some questions about Lee. Such is the case with her death certificate. No "Jarena Lee" appears in the Philadelphia death records of 1863 or early 1864, the time that the Pennsylvania Abolition Society reported her death. The city did write a death certificate of a woman named "Gerenia Lee," who died on February 5, 1864, but the information captured on this form does not match up cleanly with the details of Jarena Lee's narrative. (p. 63)

When we juxtapose Knight's archival digging with the narrative of Morrison, it becomes clear that the recurrent silences are meant to mimic the selectivity and erasure of the archives. This selectivity and erasure that comes out of the archive are what Derrida terms "archive fever" as Richard Crownshaw reminds us in "Reconsidering Postmemory: Photography, the Archive, and Post-Holocaust Memory in W.G. Sebald's "Austerlitz"." Crownshaw, drawing on Derrida's work, explains that the archive and the archivist are consumed by amnesia and obliviousness. Thus by narrating the history of Jarena Lee and Margaret Garner, Morrison produces a multilayered fiction complex enough to work against the archive and the archivist. Morrison's text works toward the restoration of the historical truth and materialization of memory. Archivization is never neutral but rather fits into a particular and suitable narrative. Much the same is true with preaching as illustrated by Baby Suggs' sermon. I mean the preacher is like the archivist. Quoting Derrida, Crownshaw defines archivization as “ . .. consignation which aims to coordinate a single corpus, in a system in which all the elements articulate the unity of an ideal configuration [...] without any heterogeneity.' (p. 219) Derrida and Crownshaw's understanding of archivization lets us infer that the archives are inherently selective. In other words, how can the archivist keep a record of such a heterogeneous body of archives without being selective. Since the archives are inherently selective, the only site that Morrison has to cure this "archive fever" is the novel. Morrison structures her narrative in such a way that the archives which draw on facts are incomplete, and the novel comes in to fill in the archival holes by collecting, salvaging, preserving, and perpetuating that which has faded from the historical record. In so doing, Morrison's novel transcends the archives. Where the archives destroy, conceal or cherrypick to preserve, Morrison's text presents itself as an alternative. Like the folk song which pits itself against the legal prohibition against literacy for the slave, Morrison's historical fiction sets itself against the sanctioned selectivity of the archives. As Crownshaw writes, echoing Derrida, "There is no preservation without destruction, "that which permits and conditions archivization."," (p. 219) The novelist, unlike the archivist is not under the constraint to destroy to preserve. There is no text of Morrison that does not have an archival texture or sub texture. Beloved, as already shown, draws on Margaret Garner's story, Home relates the Tuskegee Syphilis Study, and Song of Solomon unearths Jarena Lee's history. Through these archival textures and sub textures, Morrison compares the archives to a piece of fiction since the archivist enjoys as much discretion as to 
the writer. Morrison's creative writing process always dives into the archives to show that the archivist relates only an incomplete historiographic narrative. In so doing, Morrison text's bear's tropes that engage directly with the history that Nancy Peterson defines in her work, Against Amnesia, as "minority histories" or wounded histories which are in tension with the dominant national narrative:

Minority histories have never come into the full cultural consciousness because mainstream American history is so relentlessly optimistic and teleological that it has become painfully difficult to articulate counterhistories that do not share these values, and because postmodern culture works against the sustained engagement with memory and commitment to the complexity that is crucial for these histories. (1)

Using Mariann Hirsch's symbolism of 'photographic archive,' we can read Jarena Lee's history as the background photo on which Pilate's picture is palimpsestically drawn. Pilate's sermon stands for a memory discourse to the informed reader.

\section{Is the novel the appropriate site for sermons?}

The novel is not the appropriate site to deal with sermons nor is it the appropriate site to deal with the archives. Morrison's novel is hybridized at different levels. First, the historical referent is the first texture of hybridization; as we recall Beloved builds on Margaret Garner's history. The second texture of hybridization occurs through the sermonic and ministerial subtext that grounds the narrative. Much the same is true with Pilate's "extemporaneous sermon" which builds on Jarena Lee's history. The third level of hybridization occurs through folk songs. The sermonic subtext estranges more the novelistic discourse because, in terms of structure, the sermon follows an antidemocratic and hierarchical authoritarian paradigm while the novel is a democratic genre that does not erect a figure (preacher) who speaks while the rest of the characters (congregants) just listen. In other words, the novelistic discourse does not authorize one single voice as the sermonic discourse allows room for. One question that the reader may then ask is what is Morrison's intent in mixing these two genres. The mixing or intermixing of genres leads to "... a principle of contamination, a law of impurity, a parasitical economy" (p. 54) as Derrida argues in "The Law of Genres.' 'Derrida elaborates further that:

As soon as the word 'genre' is sounded, as soon as it is heard, as soon as one attempts to conceive it, a limit is drawn [;] as soon as genre announces itself, one must respect a norm, one must not cross a line of demarcation, one must not risk impurity, anomaly, or monstrosity... (p. 54)

If mixing of genres engenders impurity and monstrosity, then Morrison's transgressive or accidental mixing of genres raises more questions than it can provide answers. Is it that Morrison wants her novelistic discourse impure and monstrous because it deals with wounded histories and minority histories that the archives want to silence as Nancy Peterson sustains. But since the mixing of genres results from "'a parasitical economy" and has a contagious effect, we can argue that the erasure of minority voices and experiences that Morrison strives to unearth in her novelistic discourse manifests also itself in her sermonic discourse about mainstream Christianity. This claim is substantiated by the history of Jarena Lee. Also, since mixing of genres causes a 'law of impurity', as Derrida argues, Morrison's intermixing of genres speaks directly to the 'archive fever': the archives are impure and incomplete and Morrison dusts them off her historical sermonic discourse.

\section{Conclusion}

Overall, the sermons of both Baby Suggs and Pilate critique the systems of patriarchal racism and sexism that oppress women and deny them self-determination both within the church and outside of it. The literary preaching and folk song converge to otherize the novel form and at the same time point at the holes in the archives. Indeed, the historical referents that Morrison unearths engage deeply with the archives. Through these historical referents, Morrison raises the opacity of the archives. The archives are opaque and this opacity allows room for fictionality. By playing with the opacity surrounding the archives, Morrison raises the ethics of the archives. Hirsch's postmemory and Morrison's rememory are meant to dust off the opacity of the archives and preserve and pass on a bequest. Also, by setting (re)memory and postmemory against the archives, Morrison is showing that archivization or archiving has to be foregrounded on ethics for the sake of authenticity and completeness. In other words, the ethics of the archives need to be theorized to draw a clear-cut line between what archivization or archiving can leave out or not.

Sy, O. (2021). Toni Morrison's transgressive literary preaching and folk songs as postmemory. International Journal of Linguistics, Literature and Culture, 7(4), 241-254. https://doi.org/10.21744/ijllc.v7n4.1720 
Conflict of interest statement

The author declared that he has no competing interests.

Statement of authorship

The author has a responsibility for the conception and design of the study. The author has approved the final article.

Acknowledgments

I am grateful to two anonymous reviewers for their valuable comments on the earlier version of this paper. 


\section{References}

Bellah, R., Madsen, R., Sullivan, W. M., Swidler, A., \& Tipton, S. M. (1996). Individualism and the crisis of civic membership. The Christian Century, 113(16), 510-515.

Cole, S. (2021). The Autobiography as a Photograph. Academia Letters, 2.

Cone, J. H. (1977). Black theology and the black church: Where do we go from here? CrossCurrents, 27(2), 147156.

Connor, S. (2010). Thinking things. Textual Practice, 24(1), 1-20.

Crownshaw, R. (2004). Reconsidering Postmemory: Photography, the Archive, and Post-Holocaust Memory in WG Sebald's" Austerlitz". Mosaic: A Journal for the Interdisciplinary Study of Literature, 215-236.

Derrida, J. (1996). Archive fever: A Freudian impression. University of Chicago Press.

Derrida, J., \& Ronell, A. (1980). The law of genre. Critical inquiry, 7(1), 55-81.

Du Bois, W. E. B. (1994). The Souls of Black Folk/Du Bois William.

Du Bois, W. E. B. (Ed.). (1903). The Negro church: report of a social study made under the direction of Atlanta University; together with the Proceedings of the Eighth Conference for the Study of the Negro Problems, Held at Atlanta University, May 26th, 1903 (No. 8). Createspace Independent Pub.

Gepu, W., Suda, I. K., \& Suyasa, I. M. (2018). Religious conversion towards Hindu Kaharingan to Christianity. International Journal of Linguistics, Literature and Culture, 4(4), 25-37.

Gu, G. M., Martin, M. D., Darveau, R. P., Truelove, E., \& Epstein, J. (2004). Oral and serum IL-6 levels in oral lichen planus patients. Oral Surgery, Oral Medicine, Oral Pathology, Oral Radiology, and Endodontology, 98(6), 673-678. https://doi.org/10.1016/j.tripleo.2004.05.006

Hamilton, W. D. (1972). Altruism and related phenomena, mainly in social insects. Annual Review of Ecology and systematics, 3(1), 193-232.

Hirsch, M. (2001). Surviving images: Holocaust photographs and the work of postmemory. The Yale Journal of Criticism, 14(1), 5-37.

Huyssen, A. (1995). Twilight memories: Marking time in a culture of amnesia. Psychology Press.

Kim, S. H. (2002). Rapid modernisation and the future of Korean Christianity. Religion, 32(1), 27-37. https://doi.org/10.1006/reli.2002.0396

Levine, M. S. (1977). Canonical analysis and factor comparison (No. 6). Sage.

Lincoln, C. E., \& Mamiya, L. H. (1990). The black church in the African American experience. Duke University Press.

Lisa, W. (2009). Embodying American Slavery in Contemporary Culture. Urbana: $U$ of Illinois $P$.

Marable, M. (1989). African-American or Black? The Politics of Cultural Identity. Black Issues in Higher Education, 13, 72 .

Morrison, T., \& LeClair, T. (1981). The language must not sweat: A conversation with Toni Morrison. New Republic, 21, 25-29.

Myrdal, G. (1944). An American dilemma; the Negro problem and modern democracy.(2 vols.).

Najman, J. M., Williams, G. M., Keeping, J. D., Morrison, J., \& Anderson, M. J. (1988). Religious values, practices and pregnancy outcomes: A comparison of the impact of sect and mainstream Christian affiliation. Social Science \& Medicine, 26(4), 401-407. https://doi.org/10.1016/0277-9536(88)90308-5

Pattillo-McCoy, M. (1998). Church culture as a strategy of action in the black community. American Sociological Review, 767-784.

Peterson, N. J., \& Peterson, N. J. (2001). Against Amnesia: Contemporary Women Writers and the Crises of Historical Memory. University of Pennsylvania Press.

Reed, R. R. (2007). The Restorative Power of Sound: A Case for Communal Catharsis in Toni Morrison's" Beloved". Journal of Feminist Studies in Religion, 55-71.

Rose, G. (2000). Practising photography: an archive, a study, some photographs and a researcher. Journal of historical geography, 26(4), 555-571. https://doi.org/10.1006/jhge.2000.0247

Smalley, M. (2018). The Unchurched Preacher and the Circulated Sermon: Literary Preaching in Toni Morrison's Beloved. MELUS, 43(2), 29-52.

Smith, T. H. (1995). Conjuring culture: Biblical formations of black America. Oxford University Press.

Stave, S. A. (2014). From Eden to Paradise: A Pilgrimage through Toni Morrison's Trilogy. Toni Morrison: Memory and Meaning, edited by Adrienne Lanier Seward and Justine Tally, UP of Mississippi, 107-18.

van der Waal, I. (2010). Potentially malignant disorders of the oral and oropharyngeal mucosa; present concepts of management. Oral oncology, 46(6), 423-425. https://doi.org/10.1016/j.oraloncology.2010.02.016

Sy, O. (2021). Toni Morrison's transgressive literary preaching and folk songs as postmemory. International Journal of Linguistics, Literature and Culture, 7(4), 241-254. https://doi.org/10.21744/ijllc.v7n4.1720 
West, D. J. (1982). Delinquency, its roots, careers, and prospects (Vol. 50). Harvard University Press.

Woodard, H. (2019). Slave Sites on Display: Reflecting Slavery's Legacy through Contemporary" Flash" Moments. Univ. Press of Mississippi.

Wulder, M. A., White, J. C., Loveland, T. R., Woodcock, C. E., Belward, A. S., Cohen, W. B., ... \& Roy, D. P. (2016). The global Landsat archive: Status, consolidation, and direction. Remote Sensing of Environment, 185, 271-283. https://doi.org/10.1016/j.rse.2012.01.010 